\title{
CONSIDERATIONS ON THE "INTERNATIONAL CHARTER OF HUMAN RIGHTS"
}

\section{T. Tănăsescu}

\section{Tudor Tanasescu}

Faculty of Law, "Bioterra" University from Bucharest, Romania

* Correspondence: Tudor Tanasescu, Pescarusului Street, no. 3, Flat B-24.3, Floor 6, Apartment 145, Sector 2, Bucharest, Romania.

E-mail: tanasescutudor@yahoo.com

\begin{abstract}
"International Charter of human rights" is generic name under which shall meet the main international instruments relating to human rights, namely: Universal Declaration of Human Rights, the International Pact on civil and political rights, the International Pact on economic, social and cultural rights and the two optional Protocols at International Pact on civil and political rights. Documents forming "The Charter of International human rights" have represented international instruments which have been triggered an active process in the evolution of legal instruments and mechanisms consecrating and protection of the human being in universal and regional plan.

In this way at the international relations the man is now a supreme value to be protected and promoted.
\end{abstract}

Key words: charter, consecration, protection, human rights, non-discrimination.

\section{Introduction}

"International Charter of human rights" represented by the five international documents constitutes the international legal frame that marks significant changes in process of establishing a system for the protection of human rights at the level of the United Nations ${ }^{1}$. These international instruments are:

1. Universal Declaration of Human Rights;

2. International Pact on civil and political rights;

3. The international pact for the economic, social and cultural rights;

4. Optional protocol of the International Pact on civil and political rights;

5. The second optional protocol of the International Pact on civil and political rights.

The idea of making a "book of human rights" was born at the Conference in San Francisco from April to June 1945 (when was adopted the U.N. Charter - 26 June 1945), but steps taken in this respect have not been retained by the Conference and, in the end, the U.N. Charter they have laid down a few general provisions relating to fundamental human rights and freedoms.

Further proposals to the compilation of "Charter human rights" have resulted after the constitution within the framework of the Economic and Social Commission of Human Rights (16 February 1946). The Commission has been therefore entrusted to draw up "International Charter on human rights". Due to object sensitivity of this rules which was that the development of treated in the grounds may have been difficult enough, the Commission ordered gradual achievement of its adoption, respectively in the initial phase of a declaration

\footnotetext{
${ }^{1}$ Tănăsescu Tudor - International protection of human rights. University course, Sitech Publishing House, Craiova, 2013, p.12 şi 25; Niciu I. Marţian, Public international law, Servosat Publishing House, Arad, 2004, p.197; Scăunaş Stelian, International law of human rights. University course, All. Beck Publishing House, Bucharest, 2003, p.5
} 


\section{T. Tănăsescu}

and, subsequently, it is therefore necessary to develop texts of treaties which implement it. As a result, after the adoption of Universal Declaration of Human Rights have been developed and adopted much later the two tacit agreements international human rights and the first and the second optional protocol of the International Pact on civil and political rights.

The two agreements and optional protocols who took over the Universal Declaration of Human Rights but have enshrined and other rights which the Statement do not argued, thus legal instruments with vocation of universality, which have an impact, along with the Universal Declaration of Human Rights, The evolution of United Nations system for the protection of human rights, but also regional systems to this topic ${ }^{2}$.

\section{Considerations relating to the content and legal nature of the documents which} constitute the "International Charter of human rights"

\section{A. Universal Declaration of Human Rights. ${ }^{3}$}

The Universal Declaration of Human Rights has been adopted by the III ${ }^{\text {rd }}$ session of the General Assembly of U.N. on 10 December $1948 .{ }^{4}$

The declaration is the document which sets out affirmed, for the first time, fundamental rights and freedoms to be guaranteed any man or woman from around the world. The document marked the beginning of the process of edifying a seamless system with vocation of the universality guarantee and to promote human rights.

Universal Declaration of Human Rights sets out civil and political rights of man (Articles 3 to 21 ) and the economic, social and cultural rights (Articles 22 to 27).

In the first Article of the Universal Declaration of Human Rights are set out philosophical truths that stand at the basis of this document. These are: "All human beings are born free and equal before the law. They are endowed with reason and conscience and should act relative to each other in a spirit of brotherhood". Consequently, the right to liberty and equality are human rights from the moment of birth. The man is a human being equipped with reason and conscience may require certain rights.

Human Equality and non-discrimination in the application of rights and fundamental freedoms are basic principles of the declaration.

Universal Declaration of Human Rights proclaims: "Any person has the right to life, to liberty and security of person" (Article 3). These fundamental rights of human beings provides the framework for her to benefit from all other rights and fundamental freedoms. ${ }^{5}$ Article 3 of the Declaration in the series of articles, in which they are set out civil and political rights of the individual. These rights are:

- the right of every human being to life, liberty and security of its person (Article 3);

- the right not to be held in slavery or servitude (Article 4);

- the right not to be subjected to torture or inhuman or degrading treatment (Article 5);

- the right to legal recognition of each person, wherever they are (Article 6);

- the right to equality before the law and to equal protection of the law, without distinction (Article 7);

- the right to an effective satisfaction of the competent national legal bodies in the event of infringement of fundamental rights guaranteed (Article 8);

- the right not to be arrested, held or exiled arbitrarily (Article 9);

- the right to be listened to, in full equality, fair and publicly by an independent court and partially (Article 10);

- the right to the presumption of innocence until proven guilty will be legally within the framework of a public trial, with all the necessary guarantees insurance defense. Nobody

\footnotetext{
${ }^{2}$ Scăunaş Stelian, op.cit., p. 27

${ }^{3}$ The text in Vida Ioan, Human rights in the international regulations. Lumina Lex Publishing House, Bucharest, 1999, p.49-56

4 „Universal Declaration of Human Rights" was adopted with 48 votes for, 8 abstentions and no votes against. It has been adopted by Resolution no. 217, A/III

${ }^{5}$ Vezi Niciu I. Marţian, op.cit., p.198; Tănăsescu Tudor, op.cit., p.26 and Public international law. University course., The second edition revised and added, Sitech Publishing House, Craiova 2013, p.117.
} 
will be doomed to act or omission which, at the time when their heavier did not constitute criminal offenses under national law or international law (Article 11);

- the right to be protected under the law against arbitrary interference in private life, as regards family, the domicile or mail, as well as to some multi-touch brought honor or reputation of person (Article 12);

- the right to circulate freely and to choose their residence in any state (Article 13);

- the right to seek asylum and the right to benefit of the asylum-seeker in other countries in the case persecution (Article 14);

- the right of each man to a citizenship, it shall not be arbitrarily deprived of their citizenship, and the right to change his citizenship (Article 15);

- the right to marry and to found a family on the basis of equality of rights of man and woman (Article 16);

- the right of every person to property and not to be free, arbitrarily by it (Article 17);

- the right to freedom of thought, conscience and religion (Article 18);

- the right to the freedom of opinion and expression (Article 19);

- the right to freedom of assembly and of peaceful assembly association (Article 20);

- the right to take part in the public affairs of his country, either directly, or by means of elected representation and the right of everyone to have access, on an equal conditions, to public offices of his country (Article 21).

Article 22 of the Universal Declaration of Human Rights provides for the right of the individuals to social security benefits and being entitled to meet economic, social and cultural rights "indispensable for human dignity and the freedom of developments of her personality".

Universal Declaration of Human Rights proclaims the economic and cultural rights:

- the right to social security (Article 22);

- the right to work, to free choice of its work, to fair working conditions and to protection against unemployment (Article 23);

- the right to an equal wages for equal work, to an equitable remuneration and satisfactory to have him and his family an existence worthy (Article 23);

- the right to establish trade unions and to join the trade unions to defend their own interests (Article 23);

- the right to rest and leisure, as well as the periodic paid leave (Article 24);

- the right to a fair standard of living satisfactory to ensure the health and well-being and that of his family (Article 25);

- the right mother and child to the aid and special assistance (Article 25, paragraph 2);

- the right to education (Article 26);

- the right of every human being to take part in the cultural life of the Community, to enjoy the arts and to participate in scientific progress and to the blessings resulting from it (Article 27);

- the right to each man to protect the interests of moral and material arising from any scientific work, literary or artistic whose copyright is (Article 27, paragraph 2);

The last articles in the Universal Declaration (Article 28 to 30) proclaim each man to a social and international order in which the rights and freedoms set out in the declaration can be carried out fully (Article 28). Also, Specify that the man has the duties and responsibilities to the Community in which he lives, that the exercise of his rights and freedoms it is only subject to limitations meant removal of established by law, but only for the purpose of ensuring respect of recognition and rights and freedoms of others and in order to meet the requirements of fair morals, public order and general welfare in a democratic society (Article 29). Also, the Declaration stipulates that its provisions shall not be construed as would entitle a state, a group of people or a person "to engage in any activity or to commit any act which would pursue destruction of rights or freedoms set out in this Declaration" (Article 30). 


\section{T. Tănăsescu}

Universal Declaration of Human Rights does not contain provisions relating to an international system of guarantee of its provisions, it is not an international treaty generator of rights and legal obligations.

Universal Declaration of Human Rights is an act of General Assembly of U.N. has a recommendation character for the Member States of the organization, as provided by the U.N. Charter (Article 13, paragraph 1). That's why it was imposed the need that the provisions of Declaration to be included in international treaties, which to turn in legal obligations for the signatory States. ${ }^{6}$

At the $\mathrm{VI}^{\text {th }}$ session, in the year 1951, the general meeting of U.N. adopted a resolution and asked the Commission for human rights "to draw up two tacit agreements relative to international human rights, one on civil and political rights, and the other on the rights economic, social and cultural rights" (Resolution 543/VI). ${ }^{7}$

\section{B. International pacts with regard to human rights ${ }^{8}$}

The Universal Declaration of Human Rights provisions were incorporated into conventional text after 18 years through the adoption of the two international agreements in 1966.

The texts of the two international agreements with regard to human rights to the Human Rights Commission has been carried out as from the year 1952, as they are transmitted after completion, to debate and adopting General Assembly of U. N..

The proceedings of the documents in the General Assembly took place in the year 1966, and on 16 December of that year, the General Assembly of U.N., reunion held in the $\mathrm{XXI}^{\mathrm{th}}$ session, adopted, by its Resolution 220A/XXI /16.12.1966 International Pact on civil and political rights and the International Pact with regard to economic, social and cultural rights. ${ }^{9}$

On the same day, was adopted the third legal instrument - Optional Protocol to the Pact on civil and political rights ${ }^{10}$ - rules which enable and private individuals to submit complaints of Human Rights.

A second Protocol to the International Pact on civil and political rights was adopted by the General Assembly at 15 December $1989^{11}$ and affects abolish death penalty.

International covenants with regard to human rights adopted in the year 1966 shall include in addition to the two categories of provisions distinct ${ }^{22}$ (civil and political rights and economic, social and cultural rights) and more common provisions. So, in the preamble to their general sets out the principle that "the recognition of dignity inherent in all human members of the family and of their rights equal and inalienable constitutes a basis freedom, justice and peace in the world" (paragraph 1).

The two agreements have international common Articles 1, 3 and 5. In their first article shall devote this right of the peoples to dispose of them (such as the right to selfdetermination).

First article of the two agreements may provide for an obligation of States parties to encourage the attainment of people's right to dispose of them and comply with this right (item $3)$.

\footnotetext{
${ }^{6}$ The Universal Declaration of Human Rights previsions were included in 1948 in the two international agreements with regards to these rights in 1966.

${ }_{7}^{7}$ Activités de l'ONU dans le domain des droits de l'homme, New York, 1986, p9, pct.17, apud. Niciu I. Marţian, op.cit., p.199

${ }^{8}$ The texts of the two agreements in Vida Ioan, op.cit., p.56-97

${ }^{9}$ The International Pact with regard to economic, social şi cultural rights entered into force on 3 January 1976 . The Pact on civil and political rights entered into force on 23 March 1976. Romania has ratified the two agreements by D.C.S. no. 212 of 31 October 1974 (Official Gazette no. 146/20.11.1974). On 26 September 2008 were parties to the Treaties 159 states and concerned, 162 states.

${ }^{10}$ It enterded into force on 23 March 1976. Romania has acceded to this Protocol on 20 July 1993, from Law no. 39/1993. On 5 March 2008, 111 states were parties to the Protocol.

${ }^{11}$ It entered into force on 11 July 1991. Romania has become part to this Protocol on 27 February 1991, by ratifying it by Law no. 7 of 25 January 1991. On 29 September 2008 were parties to the Treaty 68 states.

${ }^{12}$ For details Beşteliu Raluca Miga and colab., International protection of human rights, Course notes, Universul juridic Publishing House, Bucharest, 2008, p.45.
} 
Article 3 of the two agreements oblige States parties to ensure that "the equal right to the man and the woman" to benefit from all the economic, social and cultural rights, as well as civil and political rights set out in these tacit agreements.

Common Article 5 provides for a "clause protection" of the rights enshrined in the two international agreements, or in other international instruments relating to human rights.

Under the aspect legal nature we remind our readers that both agreements shall be lodged in legal instruments with vocation of universality and produce legal effects in the case of member parties.

\section{Conclusions}

- "International Charter on Human Rights", for example its instruments of incorporation have triggered a process active in the evolution of legal instruments and mechanisms for the promotion and protection of the human being in universal and regional plan.

- International acts as well as Universal Declaration of Human Rights, the Pact international civil and political rights, the International Pact with regard to economic, social and cultural rights, Optional Protocol to the International Pact on civil and political rights and the second optional protocol with regard to civil and political rights, having regard generic name of "International Charter on human rights", constitute legal framework that marks significantly enhance setting up the system for the protection of human rights at the level of the United Nations.

- The provisions of the international regulations presented affects civil and political rights and economic, social and cultural rights, for example fundamental human rights and freedoms, inherent and inalienable human being.

- International documents analyzed, except Universal Declaration of Human Rights which under the aspect legal nature is only meant for a recommendation, shall be lodged in tools which produce legal effects in the case of member parties, for example generates legal obligations for them.

- Between Universal Declaration of Human Rights and the two International agreements with regard to human rights there is a close connection. As a matter of fact, international pacts in question have been accepted in their content, the provisions of Universal Declaration of Human Rights which they have turned in recommendations in legal obligations for the contracting parties.

\section{Bibliography}

1. Raluca Beşteliu Miga and collab. International protection of human rights, Course notes, Universul Juridic Publishing House, Bucharest, 2008

2. Niciu I. Marţian, Public international law, Servosat Publishing House, Arad, 2004

3. Stelian Scaunas, International law of human rights. University course, All. Beck Publishing House, Bucharest, 2003

4. Tudor Tanasescu, International protection of human rights. University course, Sitech Publishing House, Craiova, 2013

5. Tudor Tanasescu, Public international law. University course, The second edition revised and added, Sitech Publishing House, Craiova, 2013

6. Ioan Vida, Human rights in the international regulations, Lumina Lex Publishing House, Bucharest, 1999 